\title{
The Effect of Work Stress and Satisfaction of Collector Performance in PT Federal International Finance Singaraja Branch Office
}

\author{
Komang Krisna Heryanda* \\ Management Department Ganesha University of Education
}

\author{
A R T I C L E I N F O \\ Article history: \\ Received 19 February 2019 \\ Received in revised form \\ 16 March 2019 \\ Accepted 15 April 2019 \\ Available online 26 May \\ 2019 \\ Keywords: \\ job satisfaction, job stress, \\ and performance
}

\begin{abstract}
A B S T R A CT
This study aimed at determining the effect of (1) job stress and job satisfaction toward collector's performance, (2) job stress toward collector's job satisfaction, (3) job stress toward collector's performance, and (4) job satisfaction toward collector's performance at PT. Federal International Finance Singaraja Branch Office. The design of this study was causal quantitative. The populations of this study were 40 people. Data were collected by questionnaire, and analyzed by path analysis. The results showed that: (1) job stress and job satisfaction had significant effect toward collector's performance (2) job stress had a negative and significant effect toward collector job satisfaction, (3) job stress had a negative and significant effect toward collector's performance, and (4) job satisfaction had a positive and significant effect toward collector's performance at PT. Federal International Finance in Singaraja
\end{abstract}

\footnotetext{
* Corresponding author.

E-mail addresses: krisna.heryanda@gmail.com (Krisna Heryanda)
} 


\section{Introduction}

Managing human resources is very important, because in its function, human resources have a very important role in facing the flow of globalization. Human resources is also a mobility for each company. According to Hasibuan (2012: 10), that Human Resource Management (HRM) is the science and art of regulating the relationship and role of labor so that it is effective and efficient to help realizing the goals of the company, employees and society. All companies or organizations are required to have qualified human resources in carrying out the duties and objectives of the organization because each company has certain operational targets.

The occurrence of a decrease in performance can be caused by various interrelated factors; one of the factors that cause employee performance to decrease is the emotional condition of employees or stress, that can cause tension that can affect the mindset of employees. Therefore, every company is very important to manage the level of work stress of employees so that all the bad possibilities caused by employee work stress can be overcome early. To manage work stress, it can be done by doing an individual approach and can also be an organizational approach. One type of work that has high stress in carrying out its work is employees who work as collectors. Collectors are jobs that are often on the field to meet customers to collect credit. According to Habib (2015) in the research that has been carried out, that debt collectors are third parties that connect creditors and debtors in terms of credit collection, the collection can only be done if the quality of the credit bill is included in the category of doubtful or loss collectability.

The high level of work stress on employees in the collector section at PT. Federal International Finance Singaraja Branch due to the size of the target set by the company to employees. In addition to the large target, the obstacle in carrying out this work is the geographical location of Buleleng which has a lot difference so that collectors have difficulty in collecting credit for customers and hard character of each customer. Thus, it leads many customers who make the collectors stressed out in collecting credit.

In addition to work stress factors, other factors that influence low performance are job satisfaction factors. Hasibuan (2012: 202) views job satisfaction as a pleasant emotional attitude and loves his work. This attitude is reflected in work morale, discipline, and work performance.

A sense of satisfaction with the work that has been done will arise when what is expected by employees can be achieved. But in reality at PT. Federal International Finance Singaraja Branch Office, at the interview stage of a number of collector employees, many employees who were dissatisfied, especially in the collector's part, were shown in the indicators of job satisfaction as opposed to the fact that colleagues were less supportive, often unfair for one of the parties concerned, the distribution of credit collection locations so that there is a feeling of dissatisfaction in the minds of the collector's employees when the distribution is carried out. The working conditions that should be supporting employees to be comfortable while in the office are considered as the second home, but in this case the employees of PT. Federal International Finance Singaraja Branch Office has a big amount, so that it makes a lack of office space, of course it makes employees less comfortable so that job satisfaction is not achieved by employees who experience these conditions. For example, it can be seen from the parking conditions that are not comparable to the number of employees carrying vehicles, besides the perceived unfair benefits can also be a trigger for low job satisfaction.

Based on the background description of the problem above, regarding the phenomenon that occurred in the performance of collectors at PT. Federal International Finance Singaraja Branch, it is necessary to carry out the research outlined in the title "the effect of work stress and job satisfaction of the collector performance in PT. Federal International Finance Singaraja Branch Office ". This research was conducted for one month in October 2018.

The purpose of this study was to obtain explanatory findings that were tested about the following effects. (1) Job stress and job satisfaction on the performance of collectors at PT. Federal International Finance Singaraja Branch Office, (2) Job stress on collector job satisfaction at PT. Federal International Finance Singaraja Branch Office, (3) Job stress on the performance of collectors at PT. Federal International Finance Singaraja Branch Office, (4) Job satisfaction with the performance of collectors at PT. Federal International Finance Singaraja Branch Office. The results of this study are expected to contribute to the application of economics especially in the field of Human Resource Management and this research is expected to be used as reference material for future research. Practically, this research is expected to provide input and contribution to the thoughts of PT. Federal International Finance Singaraja Branch Office, especially in an effort to improve performance by paying attention to the level of work stress and job satisfaction of employees, especially to the employees of the collector's part, to be able to achieve the goals and targets of the company well and with a predetermined time period. 
Theoretically, this research is based on several theories about work stress, job satisfaction and performance. Mangkunegara (2006) "Performance is the outcome of quality and quantity and responsibility by an employee in carrying out the tasks assigned to him." According to Utomo (2017), employee performance is a series of employee actions from the process to the implementation of the activities collected to find out the results. Noor (2016) argues that in the research's performance is a comparison between the results achieved by the company and the sacrifices issued by the company, including also the resources used and costs incurred by the company. According to Kasmir (2016: 182) performance is the result of work and one's work behavior in a period, usually one year. Mangkunegara (2006) argues that, performance indicators can be grouped into four categories: (1) quality of work, (2) quantity of work, (3) reliability, and (4) attitude. These indicators can be developed by each company and can also be adjusted to the mission of each company.

Wirawan (2015) states that, the indicators used to measure performance are (1) work results consisting of indicators such as; (a) quantity of work, (b) quality of work, and (c) time efficiency in carrying out tasks, (2) work behavior which consists of (a) initiatives in developing ideas, (b) consistency of employees towards the company and (c) accuracy in work, (3) Personal characteristics which consist of some indicators such as; (a) leadership, (b) honesty in work, and (c) creativity. Indicators used to measure employee performance are theories according to Mangkunegara (2006) who argue that measures of performance indicators can be grouped into in four categories, namely (1) quality of work, (2) quantity of work, (3) reliability, and (4) attitude.

Siagian (2015: 300) states that, stress is a condition of tension that affects emotions, thoughts and physical condition of a person. According to Hasibuan (2012), stress is a condition of tension that affects emotions, thought processes, and a person's condition. Meanwhile, according to Mangkunegara (2011: 179) that, work stress is a feeling that is pressing or feeling depressed experienced by employees to face the workng activity. According to Sunyoto (2012: 63) states that, an appropriate approach is needed in managing stress, there are two approaches, such as: (1) an individual approach, in an individual approach an employee can try to reduce stress levels. So that, individual strategies like time management, physical training, relaxation exercises, and social support are needed. With good time management, an employee can complete the task well, without the demands of hasty work. With physical training, they can improve the condition of the body to be better so that they are able to face the demands of a heavy task, and (2) organizational approach, some causes of stress are demands of the tasks and organizational structures that are all controlled by management, so that these factors can be changed. Therefore the strategies that might be used by management to deal with employee stress are through selection and placement, goal setting, job design, participatory decision making, organizational communication and welfare programs. The indicator used to measure the level of work stress of employees is the theory of Mangkunegara (2011: 180 ) which suggests that there are several indicators of work stress namely (1) workload that is felt too heavy, (2) the urgentcy of work time, (3) quality of staffing low work, (4) unhealthy work climate, (5) inadequate work authority related to responsibility, (6) work conflict, and (7) differences in values between employees and leaders who are frustrated at work.

According to Hasibuan (2012: 202), job satisfaction as an emotional attitude that is pleasant and loves his work. This attitude is reflected by work morale, discipline, and work performance. Robbins (2003) states that job satisfaction is a general attitude towards one's work. The difference between the amount of rewards received by a worker and the amount they believe they should receive is matter. According to Susilo (2000: 142), job satisfaction is the emotional state of employees, where there is or does not occur a meeting point between the value of employee retribution from a company / organization with a level of reciprocity of service desired by the employee concerned. Whereas Nasution (2005) states that, job satisfaction is an emotional state of someone who feels happy because the work is in accordance with the expertise and the results of the work are given awards, praise and bonuses. The indicator used in this study is the theory of Robins (2003), namely: (1) work that is mentally challenging, (2) fair rewards and promotions, (3) supportive working conditions, and (4) supportive colleagues.

Job stress and job satisfaction influence the performance of employees in an effort to improve the performance. This is supported by the opinion of Handoko (2008) that, work stress and job satisfaction influence the performance of employees themselves. This is also stated in the research conducted by Noor (2016) that, there is a unidirectional relationship between Job Stress and Job Satisfaction on Employee Performance, and has a partial or simultaneous effect on employee performance. Then, the most influential independent variable on employee performance is work stress. According to Wala (2017), work stress and job satisfaction simultaneously have a significant positive effect on employee performance.

According to Hasibuan (2012) that, generally, the performance of employees who are stress will decrease because they have tension of the mind and act like strange behaviour, angry, and introvert. This 
is supported by a statement from Siagian (2015: 300) that, stress that is not addressed properly, usually affect the inability of a person to interact positively with his environment, both in terms of the work environment and beyond. This means that, the employees concerned will face a variety of negative symptoms which in turn affect work performance. According to Utomo (2017), stress has a negative and significant effect on employee performance, meaning that, if employee work stress decreases it can improve employee performance. While Sunyoto (2012: 62) states that, high stress levels or prolonged mild stress will reduce employee performance.

Job stress can affect job satisfaction, when employees experience high stress, it automatically creates tension of employees so that these conditions can reduce satisfaction of the employee. Robbins (2007) states that, the impact of stress on satisfaction is directly showed. In other words, tensions related to work tend to reduce job satisfaction, so that it will have an impact on decreasing performance. Amalia (2016) found that work stress has a negative effect on job satisfaction. Whereas According to Utomo (2017) revealed that if the work stress of employees decreases it can increase employee job satisfaction.

Job satisfaction has an influence on employee performance. Satisfaction can make employees work optimally so that the company's goals will be achieved within a certain time. This is supported by the opinion of Susilo (2000: 141) that, the creation of job satisfaction of members of the organization concerned will further improve work performance. According to Wala (2017), job satisfaction has a significant positive result on employee performance. This is in line with Wibowo's (2012) opinion that, employees who are satisfied with their work will have a positive impact on achieving individual performance.

\section{Method}

This study used a quantitative causal research design consisting of several stages including (1) formulating a problem, (2) studying the theory, (3) formulating a hypothesis, (4) collecting data, (5) processing data, and (6) drawing conclusions. The research subjects used in this study were employees of the collector section at PT. Federal International Finance Singaraja Branch Office, while the object of this research was work stress and job satisfaction and the performance of collector employees at PT. Federal International Finance Singaraja Branch Office. This study was categorized as population research because all populations were used as observation units or research targets in total 40 people. Data collection techniques in this study were (1) questionnaire, (2) document recording, and (3) interview, then the data obtained will be analyzed using path analysis.

Path analysis was used in this study because there were links or correlations between independent variables. Path analysis is an analysis used to analyze patterns of indirect relationships. According to Ghozali (2011: 249) path analysis is an extension of regression analysis to estimate causality between variables that have been previously determined based on theory. This analysis was used to determine the magnitude of the total effect and the direct and indirect effects of work stress variables and job satisfaction on the performance of collectors at PT. Federal International Finance Singaraja Branch Office. The data obtained from the questionnaire results for work stress variables and job satisfaction on collector performance which it was an ordinal data while the data used to prove the hypothesis must be interval data, then the data needed to be converted into interval scale through the method of successsive interval (MSI).

\section{Results and Discussion}

Based on the calculation of the Path Analysis- statistical test by using the Statistical Package for Social Science (SPSS) program 17.0 For Windows, the SPSS calculation results obtained about the effect of each variable on the performance of collectors at PT. Federal International Finance Singaraja Branch Office can be described in Figure 1 below. 


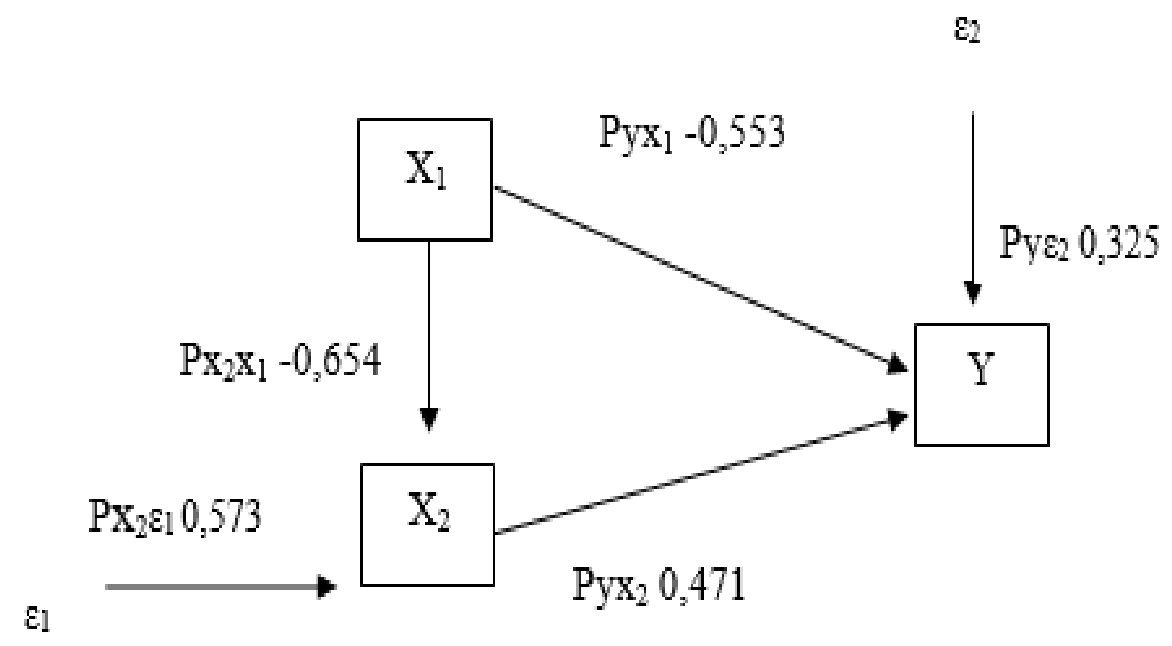

Figure 1 Effect of Job Stress Variables $\left(\mathrm{X}_{1}\right)$ and Job Satisfaction $\left(\mathrm{X}_{2}\right)$ on Collector Performance $(\mathrm{Y})$

The direct and indirect effects of work stress $\left(\mathrm{X}_{1}\right)$ and job satisfaction $\left(\mathrm{X}_{2}\right)$ on employee performance (Y) can be seen in Table 1 below.

Table 1. Contribution of the effects of variables $X_{1}$ and $X_{2}$ toward $Y$

\begin{tabular}{lll}
\hline \multicolumn{1}{c}{ Assertion } & Number of effect & Persentage \\
\hline Direct effect $\mathrm{X}_{1}$ toward $Y$ & 0,305 & $30,5 \%$ \\
Indirect effect $\mathrm{X}_{1}$ toward Y through $\mathrm{X}_{2}$ & 0,308 & $30,8 \%$ \\
An effect $\mathrm{X}_{1}$ toward $\mathrm{Y}$ & 0,613 & $61,3 \%$ \\
Direct effect $\mathrm{X}_{2}$ toward $\mathrm{Y}$ & 0,221 & $22,1 \%$ \\
The total effect of $\mathrm{X}_{1}$, and $\mathrm{X}_{2}$ toward $\mathrm{Y}$ & 0,675 & $67,5 \%$ \\
Other effect toward $\mathrm{Y}$ & 0,325 & $32,5 \%$ \\
\hline
\end{tabular}

(Resource: Output SPSS 17..0 for Windows).

Based on the results of the calculation of statistical tests Path Analysis (Job Analysis) Job stress and job satisfaction affect the performance of the collector. This is indicated by p-value Ryx1x2 $=0,000<\alpha=$ 0.05 . The effect of the joint contribution of work stress and job satisfaction on the collector's performance is 0.675 . These results indicate that $67.50 \%$ of the collector's performance is influenced by work stress variables and job satisfaction, while the influence of other variables is $32.50 \%$.

Based on the results of the calculation of the statistical test Path Analysis (Path Analysis) Job stress has a negative and significant effect on the job satisfaction of collectors at PT. Federal International Finance Singaraja Branch. This is indicated by $p$-value $\mathrm{Px} 2 \times 1=0.00<\alpha=0.05$. The influence of work stress on job satisfaction is 0.427 . These results indicate that $42.7 \%$ of employee job satisfaction is influenced by work stress, while the influence of other variables on job satisfaction is $57.3 \%$.

Based on the results of the calculation of statistical tests Path Analysis (Path Analysis), job stress has a negative and significant effect on the performance of the collector of PT. Federal International Finance Singaraja Branch Office. The closeness of the effect of work stress on the collector's performance is $55.30 \%$ and the contribution size is $30.50 \%$ with p-value Pyx $1=0,000<\alpha=0.05$. This shows that work stress has a negative effect on the performance of collectors. If the work stress of collectors is high, the collector's performance will be lower.

Based on the results of the calculation of the statistical test Path Analysis (Job Analysis), job satisfaction has a positive and significant effect on the performance of employees at PT. Federal International Finance Singaraja Branch Office. The closeness of the relationship of job satisfaction to performance is $47.10 \%$ and the large contribution of the effect of job satisfaction on performance is $22.1 \%$ with p-value Pyx2 $=0.002<\alpha=0.05$. This shows that job satisfaction has a positive effect on the performance of collectors. This means that if the job satisfaction given to collectors is good, then the collectors' performance will be higher. 
Based on the research that has been done, the findings obtained that the variables of work stress and job satisfaction jointly influence the performance of collectors at PT. Federal International Finance Singaraja Branch Office. The results of this study supported the theory according to Handoko (2008) that work stress and job satisfaction jointly influenced the performance of employees themselves. While the empirical study that supported the findings of this study wass a study conducted by Wala (2017) which states that work stress and job satisfaction simultaneously have a significant positive effect on employee performance. If the management of PT. Federal International Finance Singaraja Branch Office can manage work stress and job satisfaction well, so it can improve the performance of its collector employees. The results of subsequent studies found that work stress has a negative and significant effect on the job satisfaction of collectors at PT. Federal International Finance Singaraja Branch Office. The results of this study were also supported by the theory of Amalia (2016) found that work stress has a negative effect on job satisfaction. An empirical study that supported the results of this study is Utomo (2017) revealed that if employee work stress decreases, it can increase employee job satisfaction. The negative influence possessed by the collector's work stress can reduce satisfaction of collector employees, so that work stress must be managed as well as possible so that all the bad possibilities caused by employee work stress can be overcome early, to manage work stress can be done individually and it can also be an organizational approach.

The research on the effect of work stress variables on the performance of collectors, obtained from the results of work stress variables has a negative and significant effect on the performance of collectors at PT. Federal International Finance Singaraja Branch Office. This finding is supported by a theory from Sunyoto (2012: 62) that, high stress levels or prolonged mild stress will reduce employee performance. Empirical studies that supported the findings of this study were the results of research conducted by Utomo (2017) which states that stress has a negative and significant effect on employee performance, meaning that if employee work stress decreases, it can improve employee performance. Therefore management at PT. Federal International Finance Singaraja Branch is very necessary to manage the level of work stress from employees to improve the performance of the collector, because long-term and shortterm stress will negatively affect the performance of the collector.

The results of the subsequent research obtained were the variables of collector job satisfaction which positively and significantly affect the performance of collectors. The results of this study were in accordance with the theory revealed by Susilo (2000: 141) who found that the creation of job satisfaction of members of the organization concerned will further improve work performance. This research was also supported by empirical studies from Wala (2017) that job satisfaction has a significant positive result on employee performance. Collector at PT. Federal International Finance Singaraja Branch Office experienced a low level of satisfaction, this was caused by coworkers who were less supportive, namely the frequent perception that was felt unfair for one party, related to the distribution of credit collection locations resulting in dissatisfaction in the minds of collector employees. To get a good performance, the management of PT. Federal International Finance Singaraja Branch Office must be able to give job satisfaction to its collectors because with satisfaction employees can be more enthusiastic to work.

\section{Conclusions}

Based on the results and discussions that have been conducted, a number of conclusions can be drawn as follows: 1) Job stress and job satisfaction affect the performance of collectors at PT. Federal International Finance Singaraja Branch Office. The lower the stress of working collectors and with high job satisfaction, the higher the performance of collectors, 2) Job stress has a negative and significant effect on the job satisfaction of collectors at PT. Federal International Finance Singaraja Branch Office. The higher the work stress of collectors, the collector's job satisfaction will decrease, 3) Job stress has a negative and significant effect on the performance of collectors at PT. Federal International Finance Singaraja Branch Office. The higher the level of work stress experienced by the collector, the lower the performance of the collectors, and 4) Job satisfaction has a positive and significant effect on the performance of collectors at PT. Federal International Finance Singaraja Branch Office. The higher job satisfaction given to collectors, the performance of collectors will increase

Based on the results of research, discussion and conclusions stated above, some suggestions can be proposed as follows.

1. For the management of PT. Federal International Finance Singaraja Branch Office, it is a need to improve the performance of collectors by paying attention to the work stress of collectors through job satisfaction given, because research shows that work stress and job satisfaction can affect employee performance. To improve the performance of collectors, the company should be improved by management by paying attention to the stress level of work of the collectors because the stressful 
condition of employees will have an impact on emotions, thinking, and physical condition so that collector employees cannot work optimally in achieving performance targets. In addition to work stress, the efforts that can be made by companies in improving the performance of collectors are through the provision of job satisfaction in accordance with the workload borne by the collectors. By satisfying, collectors will be motivated to work to achieve company-specified performance standards.

2. For further researchers who are interested in examining similar aspects, like job stress, job satisfaction and employee performance, it is expected to develop this research by using broader dimensions and indicators so that the results of the study are more reliable, in addition to testing variable that allegedly can affect employee performance such as compensation, career development motivation, leadership, work environment, training, competence, and individual commitment.

\section{References}

Amalia, Uzzah Roni. 2016. Pengaruh Stres Kerja Dan Kepuasan Kerja Terhadap Kinerja Karyawan. eJournal Bisma Universitas Pendidikan Ganesha Jurusan Manajemen Volume 4.Ghozali.2011. “Aplikasi Analisis Multivariate dengan program IBM SPSS 19". Semarang:ISBN.

Habib, Ikhwan. 2015. Pertanggungjawaban Pidana Pihak Leasing Yang Mempekerjakan Debt Collector Dalam Menyelesaikan Piutang Dengan Melakukan Penganiayaan Di Kepolisian Resort Kota Pekanbaru. JOM Fakultas Hukum, Volume II, Nomor 2.

Handoko, T. Hani. 2008. Manajemen Personalia dan Sumber daya Manusia. Yogyakarta: BPFE.

Hasibuan, Malayu. S. P. 2012. Manajeman Sumber Daya Manusia. Edisi Revisi. Jakarta: PT Bumi Aksara.

Kasmir. 2016. Manajemen Sumber Daya Manusia (Teori Dan Praktik). Cetakan Ke-1 Jakarta : PT. Raja Grafindo Persada.

Mangkunegara, Anwar Prabu. 2006. Manajemen Sumber Daya Manusia Perusahaan. Bandung: PT. Remaja Rosdakarya.

2011. Perencanaan dan Pengembangan Sumber Daya Manusia. Bandung: PT. Refika Aditama.

Martoyo, Susilo. 2000. Manajemen Sumber Daya Manusia. Edisi Keempat Yogyakarta : BPFE-Yogyakarta.

Nasution, M.N. 2005. Manajeman Mutu Terpadu: Total Quality Managemant. Bogor: Ghalia Indonesia.

Noor, Nasyadizi Nilamsar. 2016. Pengaruh Stres Kerja Dan Kepuasan Kerja Terhadap Kinerja Karyawan (Studi Pada Karyawan Pt Jasaraharja Persero) Cabangjawatimur Di Surabaya). Jurnal Administrasi Bisnis, Vol. 31, No. 1.

Robbins, Stphen P. 2003. Perilaku Organisasi. Jilid-1. Edisi Indonesia. Jakarta: PT Indeks.

2007. Perilaku Organisasi. Edisi ke-10. Jakarta: PT Indeks.

Sunyoto, Danang. 2012. Teori, Kuesioner dan Analisis Data Manajemen Sumber Daya Manusia. Cetakan 1 Yogyakarta : PT. Buku Seru. 